\title{
A novel NKX2-5 loss-of-function mutation predisposes to familial dilated cardiomyopathy and arrhythmias
}

\author{
FANG YUAN ${ }^{1,2}$, XING-BIAO QIU ${ }^{2}$, RUO-GU LI² ${ }^{2}$ XIN-KAI QU ${ }^{2}$, JUAN WANG $^{3}$, \\ YING-JIA XU ${ }^{2}, \mathrm{XU} \mathrm{LIU}^{2}$, WEI-YI FANG ${ }^{2}$, YI-QING YANG $^{2,4,5}$ and DE-NING LIAO ${ }^{1}$ \\ ${ }^{1}$ Department of Cardiology, Shanghai Changzheng Hospital, Second Military Medical University, Shanghai 200003; \\ ${ }^{2}$ Department of Cardiology, Shanghai Chest Hospital, Shanghai Jiao Tong University, Shanghai 200030; \\ ${ }^{3}$ Department of Cardiology, Tongji Hospital, Tongji University School of Medicine, Shanghai 200065; \\ ${ }^{4}$ Cardiovascular Research Laboratory and ${ }^{5}$ Central Laboratory, Shanghai Chest Hospital, \\ Shanghai Jiao Tong University, Shanghai 200030, P.R. China
}

Received May 18, 2014; Accepted December 5, 2014

DOI: $10.3892 / \mathrm{ijmm} .2014 .2029$

\begin{abstract}
Dilated cardiomyopathy (DCM) is the most prevalent type of primary myocardial disease, which is the third most common cause of heart failure and the most frequent reason for heart transplantation. Aggregating evidence demonstrates that genetic risk factors are involved in the pathogenesis of idiopathic DCM. Nevertheless, DCM is of remarkable genetic heterogeneity and the genetic defects underpinning DCM in an overwhelming majority of patients remain unknown. In the present study, the whole coding exons and splice junction sites of the $N K X 2-5$ gene, which encodes a homeodomain transcription factor crucial for cardiac development and structural remodeling, were sequenced in 130 unrelated patients with idiopathic DCM. The available relatives of the index patient harboring an identified mutation and 200 unrelated ethnically matched healthy individuals used as controls were genotyped for the $N K X 2-5$ gene. The functional effect of the mutant NKX2-5 was characterized in contrast to its wild-type counterpart using a dual-luciferase reporter assay system. As a result, a novel heterozygous NKX2-5 mutation, p.S146W, was identified in a family with DCM inherited as an autosomal dominant trait, which co-segregated with DCM in the family
\end{abstract}

Correspondence to: Professor De-Ning Liao, Department of Cardiology, Shanghai Changzheng Hospital, Second Military Medical University, 415 Fengyang Road, Shanghai 200003, P.R. China

E-mail: liao6007@163.com

Professor Yi-Qing Yang, Department of Cardiology, Cardiovascular Research Laboratory and Central Laboratory, Shanghai Chest Hospital, Shanghai Jiao Tong University, 241 West Huaihai Road, Shanghai 200030, P.R. China

E-mail: yang99yang66@hotmail.com

Key words: dilated cardiomyopathy, genetics, transcription factor, NKX2-5, reporter gene with complete penetrance. Notably, the mutation carriers also had arrhythmias, such as paroxysmal atrial fibrillation and atrioventricular block. The missense mutation was absent in 400 reference chromosomes and the altered amino acid was completely conserved evolutionarily among species. Functional analysis revealed that the NKX2-5 mutant was associated with a significantly reduced transcriptional activity. The findings expand the mutational spectrum of NKX2-5 linked to DCM and provide novel insight into the molecular mechanisms underlying DCM, contributing to the antenatal prophylaxis and allele-specific management of DCM.

\section{Introduction}

Dilated cardiomyopathy (DCM) is a primary cardiac disorder characterized by ventricular chamber enlargement and systolic dysfunction with normal ventricular wall thickness in the absence of associated conditions, such as coronary artery disease, hypertension and valve disease sufficient to cause global decreased contractility (1). It is the most frequent form of non-ischemic cardiomyopathy, affecting approximately 1 in 250 individuals (2). DCM is the most common cause of chronic congestive heart failure and sudden cardiac death in individuals between the ages of 20 and 60 years, and is the leading indication for heart transplantation in both children and adult patients worldwide (1-4). A variety of etiologies has been implicated in the pathogenesis of DCM, including viral myocarditis, myocardial infarction, toxic insults, alcohol abuse, nutritional deficiencies, chronic uncontrolled tachycardia or premature ventricular contractions, autoimmune abnormalities and metabolic disorders (5). However, the majority of DCM cases remain unexplained after a thorough review for secondary causes, and such DCM is defined as idiopathic DCM, among which $25-50 \%$ of DCM cases occur in at least two closely related family members, hence termed familial DCM (3). A growing body of evidence demonstrates that genetic risk factors play a pivotal role in the pathology of DCM, and mutations in over 50 DCM genes have been described as leading to DCM in patients with familial, as well as sporadic DCM (1-3,6-8). 
The majority of the genes linked to DCM encode sarcomeric and cytoskeletal proteins, which are involved in the generation and transmission of contractile force, and are predominantly inherited in an autosomal dominant pattern, although a few follow an autosomal recessive, X-linked or mitochondrial mode of inheritance (2). Nevertheless, these established DCM-associated genes merely account for less than a third of the studied cases and each gene has a low mutational frequency, with most occurring in $<1 \%$ of patients with DCM (8). Thus, the genetic determinants responsible for DCM in an overwhelming majority of patients remain to be identified.

A number of studies have highlighted the essential roles of the cardiac transcription factors in cardiovascular development and cardiac structural remodeling, including the GATA zinc finger-containing transcription factor and the NK homeodomain transcription factor families (9-14), and a long list of mutations in GATA binding protein (GATA)4, GATA5, GATA6 and NK2 homeobox 5 (NKX2-5) have been associated with various congenital heart diseases and arrhythmias, including atrial septal defect, ventricular septal defect, tetralogy of Fallot, endocardial cushion defect, patent ductus arteriosus, double outlets of the right ventricle, pulmonary stenosis, hypoplastic right ventricle, atrial fibrillation and cardiac conduction block (15-39). Moreover, GATA4 has also been causally implicated in the development of DCM $(40,41)$.

Similar with GATA4, the homeobox transcription factor, NKX2-5, is abundantly expressed in the heart at various developmental stages and its high expression is also found in adult cardiomyocytes, where it mediates the expression of several crucial structural and regulatory genes, including those encoding atrial natriuretic factor $(\mathrm{ANF})$, brain natriuretic peptide, connexin40, troponin I, troponin $\mathrm{C}, \alpha$ - and $\beta$-myosin heavy chains $(12,42)$. The targeted disruption of $N K X 2-5$ in mice has been shown to lead to impaired cardiac growth and chamber formation, deranged gene regulatory networks and early embryonic lethality (43-45), while mice with the heterozygous or conditional deletion of $N K X 2-5$ at the postnatal stages have shown defects of late cardiomyocyte maturation and adult heart contraction, predisposing to progressive cardiomyopathy and congestive heart failure (46-48). In human families with $N K X 2-5$ mutations underlying congenital cardiovascular malformations, left ventricular contractile dysfunction and DCM as a late clinical manifestation have been observed in some mutation carriers $(35,49)$. Furthermore, NKX2-5 has been shown to physically interact with GATA4 or T-box 20 (TBX20) and synergistically regulate the expression of multiple important cardiac target genes, including those encoding ANF, $\mathrm{T}$ - and L-type $\mathrm{Ca}^{2+}$ channels, connexin40, $\alpha$-actin and leucinerich repeat containing 10 (LRRC10) (42), and loss-of-function mutations in GATA4, LRRC10, $\alpha$-actin and TBX5 have been associated with DCM $(2,40,41,50,51)$. These observational results indicate that $N K X 2-5$ is an alternative candidate gene for DCM.

\section{Subjects and methods}

Study subjects. A cohort of 130 genetically unrelated patients with idiopathic DCM was enrolled from the Han Chinese population. The available relatives of the index patients were also recruited. A total of 200 ethnically-matched unrelated healthy individuals were enlisted as the controls. All participants were evaluated by a detailed history and physical examination, chest radiography, electrocardiogram, echocardiography and an exercise performance test. Cardiac catheterization, angiography, endomyocardial biopsy and cardiac magnetic resonance imaging were performed only if there was a strong clinical indication. Medical records were also reviewed in the case of deceased or unavailable relatives. The diagnosis of idiopathic DCM was made according to the criteria established by the World Health Organization/International Society and Federation of Cardiology Task Force on the Classification of Cardiomyopathy: a left ventricular end-diastolic diameter $>27 \mathrm{~mm} / \mathrm{m}^{2}$ and an ejection fraction $<40 \%$ or fractional shortening $<25 \%$ in the absence of abnormal loading conditions, coronary artery disease, congenital heart lesions and other systemic diseases, as previously described $(40,41,52)$. Individuals were excluded if they had insufficient echocardiographic image quality or coexistent conditions that may give rise to contractile dysfunction, such as uncontrolled systemic hypertension, coronary artery disease or valvular heart disease. Familial DCM was defined when DCM occurred in two or more first-degree family relatives. Peripheral venous blood samples were obtained from all participants. The clinical analyses were conducted with investigators blinded to the genotypes. The present study was carried out in accordance with the principles of the Declaration of Helsinki and the study protocol was approved by the Institutional Ethics committee of Shanghai Chest Hospital, Shanghai, China. Written informed consent was obtained from all participants or their guardians prior to study.

Mutational analysis. Genomic DNA was extracted from the peripheral blood lymphocytes of each participant using the Wizard Genomic DNA Purification kit (Promega, Madison, WI, USA). The whole coding region and splice junction sites of the NKX2-5 gene was sequenced in the 130 unrelated patients with idiopathic DCM. When a mutation was identified in an index patient, the available relatives of the mutation carrier and the 200 unrelated healthy controls were subsequently genotyped for $N K X 2-5$. The referential genomic DNA sequence of $N K X 2-5$ was derived from GenBank (accession no. NT_023133). The primer pairs used to amplify the coding exons and flanking introns of $N K X 2-5$ by polymerase chain reaction (PCR) were designed as previously described (38). The PCR was carried out using HotStar Taq DNA Polymerase (Qiagen GmbH, Hilden, Germany) on a Veriti Thermal Cycler (Applied Biosystems, Foster, CA, USA) with standard conditions and concentrations of reagents. The amplified products were purified using the QIAquick Gel Extraction kit (Qiagen). Both strands of each PCR product were sequenced with a BigDye ${ }^{\circledR}$ Terminator version 3.1 Cycle Sequencing kit (Applied Biosystems) under an ABI PRISM 3130xl DNA Analyzer (Applied Biosystems). The DNA sequences were viewed and analyzed with the DNA Sequencing Analysis Software versoin 5.1 (Applied Biosystems). The variant was validated by re-sequencing of an independent PCR-generated amplicon from the same subject. In addition, for an identified sequence variant, the single nucleotide polymorphism (SNP; http://www.ncbi.nlm.nih.gov/SNP) and human gene mutation (HGM; http://www.hgmd.org) databases were queried to confirm its novelty. 
Comparison of amino acid sequence of NKX2-5 from various species. The amino acid sequence of human NKX2-5 predicted from GenBank (Accession no. NM_004387) was aligned with that of the chimpanzee, rhesus monkey, dog, cattle, rat, mouse, zebrafish and fowl, using the online MUSCLE program, version 3.6 (http://www.ncbi.nlm.nih.gov/).

Molecular modeling. The disease-causing potential of a NKX2-5 sequence variation was predicted by MutationTaster (an online program at http://www.mutationtaster.org), which automatically provides a probability for the variation to be either a pathogenic mutation or a benign polymorphism. Of note, the P-value used in this study is the probability of the correct prediction rather than the probability of error as used in t-test statistics (i.e., a value close to 1 indicates a high accuracy of the prediction). Additionally, another online program PolyPhen-2 (http://genetics.bwh.harvard.edu/pph2) was used to evaluate the possible effects of an amino acid substitution on the structure and function of human NKX2-5.

Expression plasmids and site-directed mutagenesis. The recombinant expression plasmid, NKX2-5-pEFSA, and the ANF-luciferase (ANF-luc) reporter plasmid, which contains the 2600-bp 5'-flanking region of the $A N F$ gene, were kindly provided by Dr Ichiro Shiojima from Chiba University School of Medicine, Chiba, Japan. The identified mutation was introduced into the wild-type NKX2-5 gene using a QuickChange II XL Site-Directed Mutagenesis kit (Stratagene, La Jolla, CA, USA) with a complementary pair of primers. The mutant was sequenced to confirm the desired mutation and to exclude any other sequence variations.

Reporter gene assays. COS-7 cells (a fibroblast-like cell line derived from monkey kidney tissue; $1 \times 10^{4}$ ), which were obtained from the Cell Bank of the Shanghai Institute of Life Science, Chinese Academy of Sciences, Shanghai, China, were plated onto a 24-well plate and cultured in Dulbecco's modified Eagle's medium supplemented with $10 \%$ fetal calf serum. The internal control reporter plasmid, pGL4.75 (hRluc/ CMV; Promega), was used in transient transfection analyses to evaluate the transcriptional activity of the $N K X 2-5$ mutant. The COS-7 cells were transfected with $0.4 \mu \mathrm{g}$ of wild-type or mutant NKX2-5-pEFSA, $1.0 \mu \mathrm{g}$ of ANF-luc, and $0.04 \mu \mathrm{g}$ of pGL4.75 using PolyFect Transfection Reagent (Qiagen). For co-transfection experiments, $0.2 \mu \mathrm{g}$ of wild-type NKX2-5-pEFSA, $0.2 \mu \mathrm{g}$ of mutant NKX2-5-pEFSA, $1.0 \mu \mathrm{g}$ of ANF-luc and $0.04 \mu \mathrm{g}$ of pGL4.75 were used. Firefly luciferase and Renilla luciferase activities were measured with the Dual-Glo Luciferase assay system (Promega) $48 \mathrm{~h}$ after transfection. The activity of the $A N F$ promoter was presented as the fold activation of firefly luciferase relative to Renilla luciferase. Three independent experiments were performed at minimum for wild-type and mutant $N K X 2-5$.

Statistical analysis. Data are expressed as the means \pm standard deviation (SD). Continuous variables were tested for normality of distribution, and the Student's unpaired t-test was used to compare the numeric variables between two groups. A comparison of the categorical variables between two groups was performed using the Pearson's $\chi^{2}$ test or Fisher's exact test
Table I. Clinical characteristics of the patients with dilated cardiomyopathy and the controls.

\begin{tabular}{lccc}
\hline Variables & $\begin{array}{c}\text { Patients } \\
(\mathrm{n}=130)\end{array}$ & $\begin{array}{c}\text { Controls } \\
(\mathrm{n}=200)\end{array}$ & P-value \\
\hline Age (years) & $46.4 \pm 12.2$ & $47.8 \pm 11.5$ & 0.2923 \\
Male (\%) & $60(46.2)$ & $93(46.5)$ & 0.9509 \\
Family history of DCM (\%) & $53(40.8)$ & $0(0)$ & $<0.0001$ \\
SBP (mmHg) & $116.3 \pm 14.5$ & $124.0 \pm 11.8$ & $<0.0001$ \\
DBP (mmHg) & $75.2 \pm 8.6$ & $84.0 \pm 7.3$ & $<0.0001$ \\
HR (bpm) & $96.5 \pm 15.0$ & $76.8 \pm 11.9$ & $<0.0001$ \\
LVEDD (mm) & $71.4 \pm 7.8$ & $46.5 \pm 6.2$ & $<0.0001$ \\
LVESD (mm) & $58.5 \pm 8.3$ & $35.2 \pm 6.1$ & $<0.0001$ \\
LVEF (\%) & $38.4 \pm 9.4$ & $64.2 \pm 7.8$ & $<0.0001$ \\
NYHA function class $(\%)$ & & & \\
I & $12(9.2)$ & NA & NA \\
II & $40(30.8)$ & NA & NA \\
III & $53(40.8)$ & NA & NA \\
IV & $25(19.2)$ & NA & NA \\
\hline
\end{tabular}

DCM, dilated cardiomyopathy; SBP, systolic blood pressure; DBP, diastolic blood pressure; HR, heart rate; LVEDD, left ventricular enddiastolic diameter; LVESD, left ventricular end-systolic diameter; LVEF, left ventricular ejection fraction; NYHA, New York Heart Association; NA, not applicable or not available.

where appropriate. A two-tailed P-value of $<0.05$ was considered to indicate a statistically significantly difference.

\section{Results}

Clinical characteristics of the study participants. A total of 130 unrelated patients with idiopathic DCM were clinically evaluated in contrast to 200 control individuals. None of the patients had overt traditional risk factors for DCM. All the patients presented with the typical DCM phenotype as previously described $(40,41,52)$. The control individuals had no evidence of structural cardiac diseases, and their echocardiogram results were normal. The baseline clinical characteristics of the study participants are summarized in Table I.

Identification of NKX2-5 mutation. The exons and exon-intron boundaries of the $N K X 2-5$ gene were sequenced in 130 index patients with idiopathic DCM, and a missense mutation was identified in the heterozygous state in a male DCM patient, with a mutational prevalence of approximately $0.77 \%$. Specifically, a substitution of guanine for cytosine in the second nucleotide of codon 146 (c.437C $>\mathrm{G})$, predicting the transition of serine (S) into tryptophan (W) at amino acid position 146 (p.S146W) was identified in the proband from family 1 . The sequence chromatograms showing the detected heterozygous $N K X 2-5$ mutation of c. $437 \mathrm{C}>\mathrm{G}$ compared with its control sequence are shown in Fig. 1. A schematic diagram of NKX2-5 protein delineating the structural domains and location of the mutation detected in the present study is presented in Fig. 2. The missense mutation was neither found in the 200 Chinese control subjects nor reported 
Table II. The phenotypic characteristics and status of NKX2-5 mutation in the living affected pedigree members.

\begin{tabular}{llccccccc}
\hline Individual & Gender & $\begin{array}{c}\text { Age } \\
\text { (years) }\end{array}$ & $\begin{array}{c}\text { Cardiac } \\
\text { phenotype }\end{array}$ & $\begin{array}{c}\text { LVEDD } \\
(\mathrm{mm})\end{array}$ & $\begin{array}{c}\text { LVESD } \\
(\mathrm{mm})\end{array}$ & LVEF (\%) & LVFS (\%) & $\begin{array}{c}\text { NKX2-5 } \\
\text { mutation }\end{array}$ \\
\hline II-1 & Male & 56 & DCM & 79 & 63 & 32 & 20 & $+/-$ \\
II-3 & Male & 50 & DCM & 60 & 42 & 35 & 27 & $+/-$ \\
III-2 & Female & 32 & DCM & 55 & 40 & 42 & 23 & $+/-$
\end{tabular}

DCM, dilated cardiomyopathy; LVEDD, left ventricular end-diastolic diameter; LVESD, left ventricular end-systolic diameter; LVEF, left ventricular ejection fraction; LVFS, left ventricular fractional shortening; +/-, heterozygous mutation.

Table III. NKX2-5 sequence variations identified in the present study.

\begin{tabular}{lllll}
\hline & & & \multicolumn{2}{c}{ Allele frequency } \\
\cline { 4 - 4 } Location & Nucleotide & Amino acid & Patients & Controls \\
\hline Exon 1 & c.63A $>\mathrm{G}$ & p.E21E & $(0.238) 62 / 260$ & $(0.233) 93 / 400$ \\
Exon 2 & c. $437 \mathrm{C}>\mathrm{G}$ & p.S146W & $(0.004) 1 / 260$ & $(0.000) 0 / 400$ \\
Exon 2 & c. $606 \mathrm{C}>\mathrm{G}$ & p.L202L & $(0.012) 3 / 260$ & $(0.015) 6 / 400$ \\
\hline
\end{tabular}

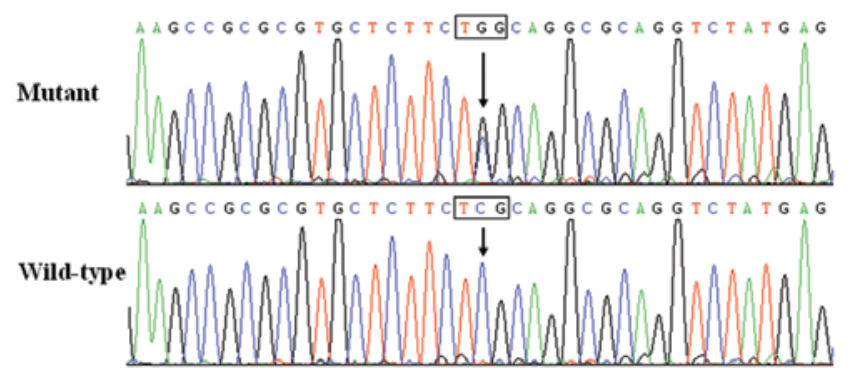

Figure 1. Sequence electropherograms showing the heterozygous $N K X 2-5$ variation compared with its control. The arrow points to the heterozygous nucleotides of $\mathrm{G} / \mathrm{C}$ in the proband (mutant) or the homozygous nucleotides of $\mathrm{C} / \mathrm{C}$ in the corresponding control individual (wild-type). The rectangle denotes the nucleotides comprising a codon of NKX2-5.

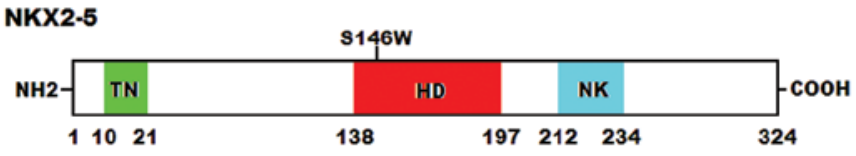

Figure 2. Schematic diagram of NKX2-5 protein structure with the dilated cardiomyopathy-associated mutation indicated. The mutation identified in patients with familial dilated cardiomyopathy is marked above the structural domains. $\mathrm{NH} 2$, amino-terminus; TN, transcriptional activation domain; HD, homeodomain; NK, NK2-specific domain; $\mathrm{COOH}$, carboxyl-terminus.

in the public databases for human sequence variations including the SNP and HGM databases, indicating that it was a novel mutation. The genetic screening of the family revealed that the mutation was present in all affected living family members, but absent in the unaffected family members examined. Analysis of the pedigree demonstrated that the mutation co-segregated with DCM transmitted as an autosomal dominant trait in the

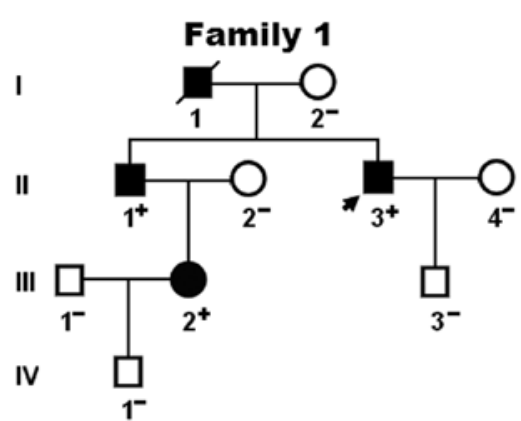

Figure 3. Pedigree structure of the family with dilated cardiomyopathy. Family members are identified by generations and numbers. Square, male family member; circle, female member; symbol with a slash, the deceased member; closed symbol, affected member; open symbol, unaffected member; arrow, proband; + , carrier of the heterozygous missense mutation; -, non-carrier.

family with complete penetrance. The pedigree structure of the family is displayed in Fig. 3. The phenotypic characteristics and status of the NKX2-5 mutation of the affected living family members are listed in Table II.

Of note, the proband's father (I-1) also had atrial fibrillation, third-degree atrioventricular block and frequent premature ventricular contractions, and died suddenly at the age of 49; the proband's brother (II-1) also had paroxysmal atrial fibrillation, second-degree atrioventricular block and premature ventricular contractions; and the proband (II-3) and his niece (III-2) also had premature ventricular contractions. In addition, two $N K X 2-5$ polymorphisms, c. $63 \mathrm{~A}>\mathrm{G}$ and c. $606 \mathrm{C}>\mathrm{G}$, were observed in both DCM patients and control individuals. However, there was no significant difference in either of the two allele frequencies between the DCM patient and healthy control groups. All the sequence variants and their allele frequencies are listed in Table III. 


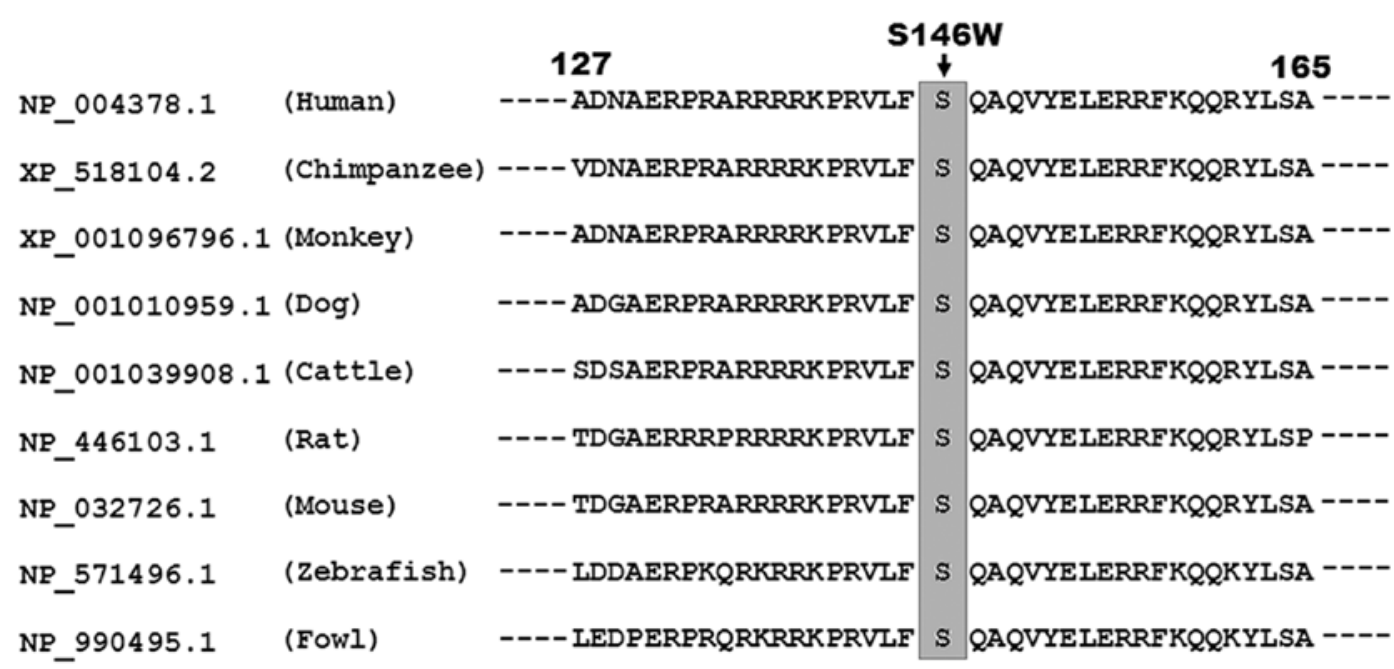

Figure 4. Multiple alignments of NKX2-5 protein sequences from various species. The altered amino acid of p.S145W is completely conserved evolutionarily across species.

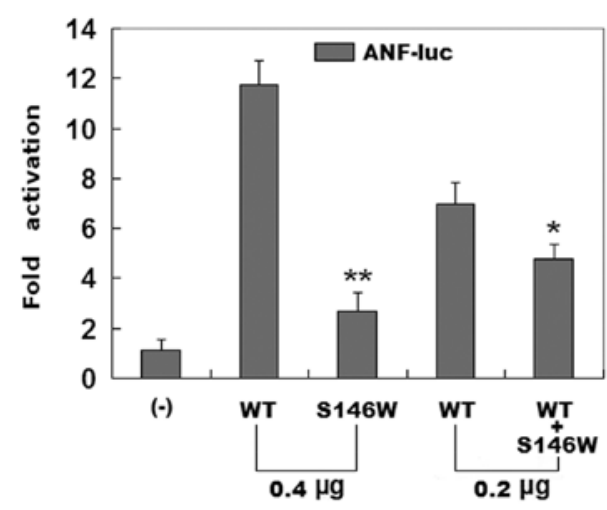

Figure 5. Functional defect caused by NKX2-5 mutation. Activation of atrial natriuretic factor (ANF) promoter driven luciferase reporter in COS-7 cells by wild-type (WT) or S146W-mutant NKX2-5, alone or together, showed significantly reduced transcriptional activation by the mutant protein. Experiments were performed in triplicate, and the mean and standard deviations are shown. ${ }^{* *} \mathrm{P}<0.0005$ and ${ }^{*} \mathrm{P}<0.001$, respectively, when compared with wild-type NKX2-5.

Alignment of multiple NKX2-5 protein sequences from various species. A cross-species alignment of NKX2-5 protein sequences demonstrated that the altered amino acid p.S146 was completely conserved evolutionarily in various species (Fig. 4).

Functional modeling in silico. The NKX2-5 sequence variation of c. $437 \mathrm{C}>\mathrm{G}$ was predicted by MutationTaster to be a pathogenic mutation with a P-value of nearly 1.0. No SNPs in the altered region were found in the MutationTaster database. This amino acid substitution was also predicted by PolyPhen-2 to be probably damaging, with a score of 1.000 (sensitivity, 0.00 ; specificity, 1.00).

Reduced transcriptional activity of the NKX2-5 mutant. As shown in Fig. 5, the same amount $(0.4 \mu \mathrm{g})$ of wild-type and mutant NKX2-5 activated the $A N F$ promoter by $\sim 12$-fold and $\sim 3$-fold, respectively. When the same amount of wild-type
NKX2-5 $(0.2 \mu \mathrm{g})$ was co-transfected with mutant NKX2-5 $(0.2 \mu \mathrm{g})$, the induced activation of the $A N F$ promoter was $\sim 5$-fold. These results demonstrate that the NKX2-5 mutant has a significantly reduced activation activity compared with its wild-type counterpart.

\section{Discussion}

In the present study, a heterozygous DCM-associated sequence variation, p.S146W, was identified in the $N K X 2-5$ gene, which was not found in either 400 reference chromosomes or public databases for sequence variations including the SNP and HGM databases. This variant affected the amino acid that was completely conserved evolutionarily, and was predicted to be a causative mutation by the MutationTaster and PolyPhen-2 databases. The missense mutation co-segregated with DCM, as well as arrhythmias in the family with complete penetrance. Functional analysis unveiled that the mutant NKX2-5 was associated with significantly decreased transcriptional activity. Therefore, it is possible that NKX2-5 loss-of-function mutation predisposes these mutation carriers to DCM and arrhythmias.

It has been substantiated that NKX2-5 is an upstream regulator of multiple genes expressed during cardiac morphogenesis, including the $A N F$ gene (42). Therefore, the functional characteristics of the NKX2-5 mutation may be deciphered by analyzing the transcriptional activity of the $A N F$ promoter in cells expressing NKX2-5. In the present study, the functional effect of the novel NKX2-5 mutation (p.S146W) identified in the patients with familial DCM was characterized by transcriptional activity analysis and the results demonstrated that the mutant NKX2-5 was associated with a significantly diminished transcriptional activity. These findings suggest that haploinsufficiency or the dominant-negative effect caused by the NKX2-5 mutation is potentially an alternative pathological mechanism of DCM.

The association of NKX2-5 loss-of-function mutation with enhanced susceptibility to DCM has been previously investigated. Costa et al (53) performed mutational screening of 
NKX2-5 in 220 probands with adult-onset DCM, and identified three missense mutations in three probands in addition to three synonymous polymorphisms, with a mutational prevalence of approximately $1.36 \%$. The three mutations included two previously reported mutations (p.R25C and p.A119S) and one novel mutation (p.I184M). The p.R25C and p.A119S mutations have been reported to result in reduced DNA binding and transactivation properties, and the former has been associated with congenital cardiovascular deformities and thyroid dysgenesis while the latter has been related to thyroid ectopy (49,54-58). The novel p.I184M mutation was identified in a proband with familial DCM and genetic analysis of the family showed that the mutation was present in all affected family members. Functional analysis of p.I184M in vitro demonstrated a significant decrease in DNA binding activity despite the increased expression level of the mutant protein due to reduced degradation via the ubiquitin-proteasome system, resulting in the diminished activation of target genes. Notably, in a total of five mutation carriers of the family, one had DCM, atrial septal defect, atrial fibrillation and right bundle branch block; another had DCM, patent foramen ovale and complete heart block; a third had DCM, atrial septal defect and right bundle branch block; the other two had only tricuspid atresia and right bundle branch block, respectively (53). Similarly, in the present study, the mutation carriers also presented with DCM and arrhythmias, including atrial fibrillation and progressive cardiac conduction block, underlining the crucial role of NKX2-5 in the embryonic heart development and postnatal cardiac adaptation.

The findings that functionally defective NKX2-5 enhances the susceptibility to DCM may be partially attributed to the developmental and regenerative defects of the myocardium as well as abnormal heart remodeling (10). As a critical regulator of the cardiac gene network and heart development, NKX2-5 is highly expressed in early heart progenitor cells that commit to the cardiac lineage during embryogenesis, and continues abundant expression in the heart throughout adulthood (43,59-62). Three independent NKX2-5-null mouse models showed a uniform phenotype of lethality between E9-10 associated with arrested heart tube looping morphogenesis and growth retardation, with the expression of several prominent cardiac structural and transcriptional regulatory genes downregulated (44,63-67). NKX2-5 also plays an important part in the postnatal maturation and homeostasis of cardiomyocytes and the functional adaptation of adult heart. In a feline model of right-ventricular pressure overload conferred by banding of the pulmonary artery, or in adult mice with adrenergic-induced cardiac hypertrophy, the expression of NKX2-5 was upregulated, suggesting that NKX2-5 participates in the cardiac hypertrophic response during pressure overload or stress stimulation $(68,69)$. By contrast, the expression of a dominantnegative human NKX2-5 mutant in the mouse heart under the control of $\alpha$-myosin heavy chain ( $\alpha$-MHC) promoter induced cardiac dysfunction and degeneration, and injection of doxorubicin promoted more severe cardiac dysfunction and increased cardiomyocyte apoptosis $(70,71)$. Furthermore, NKX2-5 has been documented to promote cardiomyocyte differentiation and modulate adult cardiac hypertrophic response through interacting with other cardiac transcription factors, such as TBX5, GATA4, serum response factor (SRF) and calmodulin binding transcription activator 2 (CAMTA2) (72-76). In addition, NKX2-5 also regulates expression of gap junction protein connexin43 and sarcomere organization in postnatal cardiomyocytes (77), indicating the cardioprotective role of NKX2-5 as a survival factor in the heart.

Notably, a great number of NKX2-5 mutations have been previously associated with a wide variety of congenital cardiovascular anomalies, including atrial septal defect, ventricular septal defect, tetralogy of Fallot, double outlet right ventricle, L-transposition of the great artery and hypoplastic left heart syndrome $(35,39,49,54-57,78-84)$. However, in the present study, the patients harboring the identified NKX2-5 mutation presented with DCM and arrhythmias, but without cardiovascular malformations. The remarkable discrepancy in the phenotypes of NKX2-5 genotypes may be explained by the following reasons. Firstly, considering some congenital cardiac structural aberrations may restore spontaneously, we cannot rule out the possibility that some mutation carriers had minor cardiac septal defects that closed shortly after birth on their own (26). Next, genomic imprinting results in preferential expression of the paternal or maternal allele of a certain gene, underlining the effect of proband (85). Thirdly, the nature of a mutation (loss-of-function, dominant-negative or gain-of-function effect) and its temporal and spatial effect during cardiac development (germline or somatic) are a potential explanation for this phenomenon $(49,54)$. Fourthly, different genetic backgrounds, including possibly common SNPs altering disease susceptibility, are responsible for the marked phenotypic heterogeneity of the genotype (86-88). Finally, mutations like p.S146W may be a genetic modifying factor that confers vulnerability to congenital heart diseases, rather than a direct cause, and environmental risk factors may be required for the onset of congenital cardiac abnormalities.

In conclusion, the data from the present study suggests that the NKX2-5 loss-of-function mutation contributes to the pathogenesis of DCM, suggesting potential implications in genetic testing that can help improve the care of patients and families with DCM.

\section{Acknowledgements}

The authors are extremely grateful to the participants for their participation in the study. The present study was supported in part by grants from the National Natural Science Fund of China (81270161, 81271927 and 81370301), the Natural Science Fund of Shanghai, China (13ZR1438400), the Fundamental Research Fund for Central University of Ministry of Education, China (15072), the Scientific Research Fund of Health Bureau, Shanghai, China (2010119) and the Excellent Discipline Leader Training Foundation of Pudong New Strict, Shanghai, China (PWRd2012-05).

\section{References}

1. Garcia-Pavia P, Cobo-Marcos M, Guzzo-Merello G, Gomez-Bueno M, Bornstein B, Lara-Pezzi E, Segovia J and Alonso-Pulpon L: Genetics in dilated cardiomyopathy. Biomark Med 7: 517-533, 2013.

2. Hershberger RE, Hedges DJ and Morales A: Dilated cardiomyopathy: the complexity of a diverse genetic architecture. Nat Rev Cardiol 10: 531-547, 2013. 
3. McNally EM, Golbus JR and Puckelwartz MJ: Genetic mutations and mechanisms in dilated cardiomyopathy. J Clin Invest 123: 19-26, 2013.

4. Koutalas E, Kanoupakis E and Vardas P: Sudden cardiac death in non-ischemic dilated cardiomyopathy: a critical appraisal of existing and potential risk stratification tools. Int J Cardiol 167: 335-341, 2013.

5. Yoshikawa T: Contribution of acquired factors to the pathogenesis of dilated cardiomyopathy. The cause of dilated cardiomyopathy: genetic or acquired? (Acquired-Side). Circ J 75: 1766-1773, 2011

6. Refaat MM, Lubitz SA, Makino S, Islam Z, Frangiskakis JM, Mehdi H, Gutmann R, Zhang ML, Bloom HL, MacRae CA, Dudley SC, Shalaby AA, Weiss R, McNamara DM, London B and Ellinor PT: Genetic variation in the alternative splicing regulator RBM20 is associated with dilated cardiomyopathy. Heart Rhythm 9: 390-396, 2012.

7. Wahbi K, Béhin A, Bécane HM, Leturcq F, Cossée M, Laforêt P, Stojkovic T, Carlier P, Toussaint M, Gaxotte V, Cluzel P, Eymard B and Duboc D: Dilated cardiomyopathy in patients with mutations in anoctamin 5. Int J Cardiol 168: 76-79, 2013.

8. Flack E and Kannankeril PJ: The genetics of dilated cardiomyopathy. Heart Rhythm 9: 397-398, 2012.

9. Pikkarainen S, Tokola H, Kerkelä R and Ruskoaho H: GATA transcription factors in the developing and adult heart. Cardiovasc Res 63: 196-207, 2004.

10. Oka T, Xu J and Molkentin JD: Re-employment of developmental transcription factors in adult heart disease. Semin Cell Dev Biol 18: 117-131, 2007.

11. Kikuchi K, Holdway JE, Werdich AA, Anderson RM, Fang Y, Egnaczyk GF, Evans T, Macrae CA, Stainier DY and Poss KD Primary contribution to zebrafish heart regeneration by gata4+ cardiomyocytes. Nature 464: 601-605, 2010.

12. Akazawa $\mathrm{H}$ and Komuro I: Cardiac transcription factor Csx/ Nkx2-5: its role in cardiac development and diseases. Pharmacol Ther 107: 252-268, 2005

13. Kasahara A, Cipolat S, Chen Y, Dorn GW II and Scorrano L: Mitochondrial fusion directs cardiomyocyte differentiation via calcineurin and Notch signaling. Science 342: 734-737, 2013.

14. Cai H, Katoh-Kurasawa M, Muramoto T, Santhanam B, Long Y, Li L, Ueda M, Iglesias PA, Shaulsky G and Devreotes PN: Nucleocytoplasmic shuttling of a GATA transcription factor functions as a development timer. Science 343: 1249531, 2014.

15. Garg V, Kathiriya IS, Barnes R, Schluterman MK, King IN, Butler CA, Rothrock CR, Eapen RS, Hirayama-Yamada K, Joo K, Matsuoka R, Cohen JC and Srivastava D: GATA4 mutations cause human congenital heart defects and reveal an interaction with TBX5. Nature 424: 443-447, 2003.

16. Rajagopal SK, Ma Q, Obler D, Shen J, Manichaikul A, TomitaMitchell A, Boardman K, Briggs C, Garg V, Srivastava D, Goldmuntz E, Broman KW, Benson DW, Smoot LB and Pu WT: Spectrum of heart disease associated with murine and human GATA4 mutation. J Mol Cell Cardiol 43: 677-685, 2007.

17. Yang YQ, Li L, Wang J, Liu XY, Chen XZ, Zhang W, Wang XZ, Jiang JQ, Liu X and Fang WY: A novel GATA4 loss-of-function mutation associated with congenital ventricular septal defect. Pediatr Cardiol 33: 539-546, 2012.

18. Wang J, Sun YM and Yang YQ: Mutation spectrum of the GATA4 gene in patients with idiopathic atrial fibrillation. Mol Biol Rep 39: 8127-8135, 2012.

19. Yang YQ, Wang J, Liu XY, Chen XZ, Zhang W and Wang XZ: Mutation spectrum of GATA4 associated with congenital atrial septal defects. Arch Med Sci 9: 976-983, 2013.

20. Yang YQ, Gharibeh L, Li RG, Xin YF, Wang J, Liu ZM, Qiu XB, Xu YJ, Xu L, Qu XK, Liu X, Fang WY, Huang RT, Xue S and Nemer G: GATA4 loss-of-function mutations underlie familial tetralogy of fallot. Hum Mutat 34: 1662-1671, 2013.

21. Yang YQ, Wang J, Wang XH, Wang Q, Tan HW, Zhang M, Shen FF, Jiang JQ, Fang WY and Liu X: Mutational spectrum of the GATA5 gene associated with familial atrial fibrillation. Int J Cardiol 157: 305-307, 2012

22. Gu JY, Xu JH, Yu H and Yang YQ: Novel GATA5 loss-offunction mutations underlie familial atrial fibrillation. Clinics (Sao Paulo) 67: 1393-1399, 2012

23. Jiang JQ, Li RG, Wang J, Liu XY, Xu YJ, Fang WY, Chen XZ, Zhang W, Wang XZ and Yang YQ: Prevalence and spectrum of GATA5 mutations associated with congenital heart disease. Int J Cardiol 165: 570-573, 2013

24. Wei D, Bao H, Zhou N, Zheng GF, Liu XY and Yang YQ: GATA5 loss-of-function mutation responsible for the congenital ventriculoseptal defect. Pediatr Cardiol 34: 504-511, 2013.
25. Wei D, Bao H, Liu XY, Zhou N, Wang Q, Li RG, Xu YJ and Yang YQ: GATA5 loss-of-function mutations underlie tetralogy of fallot. Int J Med Sci 10: 34-42, 2013.

26. Wang XH, Huang CX, Wang Q, Li RG, Xu YJ, Liu X, Fang WY and Yang YQ: A novel GATA5 loss-of-function mutation underlies lone atrial fibrillation. Int J Mol Med 31: 43-50, 2013.

27. Shi LM, Tao JW, Qiu XB, Wang J, Yuan F, Xu L, Liu H, Li RG, Xu YJ, Wang Q, Zheng HZ, Li X, Wang XZ, Zhang M, Qu XK and Yang YQ: GATA5 loss-of-function mutations associated with congenital bicuspid aortic valve. Int J Mol Med 33: 1219-1226, 2014.

28. Huang RT, Xue S, Xu YJ, Zhou M and Yang YQ: Somatic GATA5 mutations in sporadic tetralogy of Fallot. Int J Mol Med 33: 1227-1235, 2014

29. Zheng GF, Wei D, Zhao H, Zhou N, Yang YQ and Liu XY: A novel GATA6 mutation associated with congenital ventricular septal defect. Int J Mol Med 29: 1065-1071, 2012

30. Wang J, Luo XJ, Xin YF, Liu Y, Liu ZM, Wang Q, Li RG, Fang WY, Wang XZ and Yang YQ: Novel GATA6 mutations associated with congenital ventricular septal defect or tetralogy of fallot. DNA Cell Biol 31: 1610-1617, 2012.

31. Yang YQ, Wang XH, Tan HW, Jiang WF, Fang WY and Liu X: Prevalence and spectrum of GATA6 mutations associated with familial atrial fibrillation. Int J Cardiol 155: 494-496, 2012.

32. Yang YQ, Li L, Wang J, Zhang XL, Li RG, Xu YJ, Tan HW, Wang XH, Jiang JQ, Fang WY and Liu X: GATA6 loss-offunction mutation in atrial fibrillation. Eur J Med Genet 55: 520-526, 2012

33. Li J, Liu WD, Yang ZL and Yang YQ: Novel GATA6 loss-offunction mutation responsible for familial atrial fibrillation. Int J Mol Med 30: 783-790, 2012.

34. Huang RT, Xue S, Xu YJ and Yang YQ: Somatic mutations in the GATA6 gene underlie sporadic tetralogy of Fallot. Int J Mol Med 31: 51-58, 2013

35. Schott JJ, Benson DW, Basson CT, Pease W, Silberbach GM, Moak JP, Maron BJ, Seidman CE and Seidman JG: Congenital heart disease caused by mutations in the transcription factor NKX2-5. Science 281: 108-111, 1998.

36. Guntheroth W, Chun L, Patton KK, Matsushita MM, Page RL and Raskind WH: Wenckebach periodicity at rest that normalizes with tachycardia in a family with a NKX2.5 mutation. Am J Cardiol 110: 1646-1650, 2012.

37. Xie WH, Chang C, Xu YJ, Li RG, Qu XK, Fang WY, Liu X and Yang YQ: Prevalence and spectrum of Nkx2.5 mutations associated with idiopathic atrial fibrillation. Clinics (Sao Paulo) 68: 777-784, 2013

38. Huang RT, Xue S, Xu YJ, Zhou M and Yang YQ: A novel NKX2.5 loss-of-function mutation responsible for familial atrial fibrillation. Int J Mol Med 31: 1119-1126, 2013.

39. McCulley DJ and Black BL: Transcription factor pathways and congenital heart disease. Curr Top Dev Biol 100: 253-277, 2012.

40. Li RG, Li L, Qiu XB, Yuan F, Xu L, Li X, Xu YJ, Jiang WF, Jiang JQ, Liu X, Fang WY, Zhang M, Peng LY, Qu XK and Yang YQ: GATA4 loss-of-function mutation underlies familial dilated cardiomyopathy. Biochem Biophys Res Commun 439: 591-596, 2013.

41. Zhao L, Xu JH, Xu WJ, Yu H, Wang Q, Zheng HZ, Jiang WF, Jiang JF and Yang YQ: A novel GATA4 loss-of-function mutation responsible for familial dilated cardiomyopathy. Int J Mol Med 33: 654-660, 2014

42. Brody MJ, Cho E, Mysliwiec MR, Kim TG, Carlson CD, Lee KH and Lee Y: LrrclO is a novel cardiac-specific target gene of Nkx2-5 and GATA4. J Mol Cell Cardiol 62: 237-246, 2013.

43. Lints TJ, Parsons LM, Hartley L, Lyons I and Harvey RP: $\mathrm{Nkx}-2.5$ : a novel murine homeobox gene expressed in early heart progenitor cells and their myogenic descendants. Development 119: 419-431, 1993

44. Lyons I, Parsons LM, Hartley L, Li R, Andrews JE, Robb L and Harvey RP: Myogenic and morphogenetic defects in the heart tubes of murine embryos lacking the homeo box gene $\mathrm{Nkx} 2-5$. Genes Dev 9: 1654-1666, 1995.

45. Prall OW, Menon MK, Solloway MJ, Watanabe Y, Zaffran S, Bajolle F, Biben C, McBride JJ, Robertson BR, Chaulet H, Stennard FA, Wise N, Schaft D, Wolstein O, Furtado MB, Shiratori H, Chien KR, Hamada H, Black BL, Saga Y, Robertson EJ, Buckingham ME and Harvey RP: An Nkx2-5/ Bmp2/Smad1 negative feedback loop controls heart progenitor specification and proliferation. Cell 128: 947-959, 2007. 
46. Pashmforoush M, Lu JT, Chen H, Amand TS, Kondo R, Pradervand S, Evans SM, Clark B, Feramisco JR, Giles W, Ho SY, Benson DW, Silberbach M, Shou W and Chien KR: Nkx2-5 pathways and congenital heart disease; loss of ventricular myocyte lineage specification leads to progressive cardiomyopathy and complete heart block. Cell 117: 373-386, 2004.

47. Briggs LE, Takeda M, Cuadra AE, Wakimoto H, Marks MH, Walker AJ, Seki T, Oh SP, Lu JT, Sumners C, Raizada MK, Horikoshi N, Weinberg EO, Yasui K, Ikeda Y, Chien KR and Kasahara H: Perinatal loss of Nkx2-5 results in rapid conduction and contraction defects. Circ Res 103: 580-590, 2008.

48. Takeda M, Briggs LE, Wakimoto H, Marks MH, Warren SA, Lu JT, Weinberg EO, Robertson KD, Chien KR and Kasahara H: Slow progressive conduction and contraction defects in loss of Nkx2-5 mice after cardiomyocyte terminal differentiation. Lab Invest 89: 983-993, 2009.

49. Benson DW, Silberbach GM, Kavanaugh-McHugh A, Cottrill C, Zhang Y, Riggs S, Smalls O, Johnson MC, Watson MS, Seidman JG, Seidman CE, Plowden J and Kugler JD: Mutations in the cardiac transcription factor NKX2.5 affect diverse cardiac developmental pathways. J Clin Invest 104: 1567-1573, 1999.

50. Kirk EP, Sunde M, Costa MW, Rankin SA, Wolstein O, Castro ML, Butler TL, Hyun C, Guo G, Otway R, Mackay JP, Waddell LB, Cole AD, Hayward C, Keogh A, Macdonald P, Griffiths L, Fatkin D, Sholler GF, Zorn AM, Feneley MP, Winlaw DS and Harvey RP: Mutations in cardiac T-box factor gene TBX20 are associated with diverse cardiac pathologies, including defects of septation and valvulogenesis and cardiomyopathy. Am J Hum Genet 81: 280-291, 2007.

51. Brody MJ, Hacker TA, Patel JR, Feng L, Sadoshima J, Tevosian SG, Balijepalli RC, Moss RL and Lee Y: Ablation of the cardiac-specific gene leucine-rich repeat containing 10 (Lrrc10) results in dilated cardiomyopathy. PLoS One 7: e51621, 2012

52. Elliott P, O'Mahony C, Syrris P, Evans A, Rivera Sorensen C, Sheppard MN, Carr-White G, Pantazis A and McKenna WJ Prevalence of desmosomal protein gene mutations in patients with dilated cardiomyopathy. Circ Cardiovasc Genet 3: 314-322, 2010.

53. Costa MW, Guo G, Wolstein O, Vale M, Castro ML, Wang L, Otway R, Riek P, Cochrane N, Furtado M, Semsarian C, Weintraub RG, Yeoh T, Hayward C, Keogh A, Macdonald P, Feneley M, Graham RM, Seidman JG, Seidman CE, Rosenthal N Fatkin D and Harvey RP: Functional characterization of a novel mutation in NKX2-5 associated with congenital heart disease and adult-onset cardiomyopathy. Circ Cardiovasc Genet 6: 238-247, 2013

54. Kasahara H, Lee B, Schott JJ, Benson DW, Seidman JG, Seidman CE and Izumo S: Loss of function and inhibitory effects of human CSX/NKX2.5 homeoprotein mutations associated with congenital heart disease. J Clin Invest 106: 299-308, 2000.

55. Goldmuntz E, Geiger E and Benson DW: NKX2.5 mutations in patients with tetralogy of fallot. Circulation 104: 2565-2568, 2001.

56. Stallmeyer B, Fenge H, Nowak-Göttl U and Schulze-Bahr E: Mutational spectrum in the cardiac transcription factor gene $N K X 2.5(C S X)$ associated with congenital heart disease. Clin Genet 78: 533-540, 2010.

57. Beffagna G, Cecchetto A, Dal Bianco L, Lorenzon A, Angelini A, Padalino M, Vida V, Bhattacharya S, Stellin G, Rampazzo A and Daliento L: R25C mutation in the NKX2.5 gene in Italian patients affected with non-syndromic and syndromic congenital heart disease. J Cardiovasc Med (Hagerstown) 14: 582-586, 2013

58. Dentice M, Cordeddu V, Rosica A, Ferrara AM, Santarpia L, Salvatore D, Chiovato L, Perri A, Moschini L, Fazzini C, Olivieri A, Costa P, Stoppioni V, Baserga M, De Felice M, Sorcini M, Fenzi G, Di Lauro R, Tartaglia M and Macchia PE: Missense mutation in the transcription factor NKX2-5: a novel molecular event in the pathogenesis of thyroid dysgenesis. J Clin Endocrinol Metab 91: 1428-1433, 2006.

59. Komuro I and Izumo S: Csx: a murine homeobox-containing gene specifically expressed in the developing heart. Proc Natl Acad Sci USA 90: 81458149, 1993

60. Kasahara H, Bartunkova S, Schinke M, Tanaka M and Izumo S: Cardiac and extracardiac expression of Csx/Nkx2.5 homeodomain protein. Circ Res 82: 936-946, 1998.

61. Stanley EG, Biben C, Elefanty A, Barnett L, Koentgen F, Robb L and Harvey RP: Efficient Cre-mediated deletion in cardiac progenitor cells conferred by a 3'UTR-ires-Cre allele of the homeobox gene Nkx2-5. Int J Dev Biol 46: 431-439, 2002.
62. Schlesinger J, Schueler M, Grunert M, Fischer JJ, Zhang Q, Krueger T, Lange M, Tönjes M, Dunkel I and Sperling SR: The cardiac transcription network modulated by Gata4, Mef2a, Nkx2.5, Srf, histone modifications, and microRNAs. PLoS Genet 7: e1001313,2011.

63. Shin CH, Liu ZP, Passier R, Zhang CL, Wang DZ, Harris TM, Yamagishi H, Richardson JA, Childs G and Olson EN: Modulation of cardiac growth and development by HOP, an unusual homeodomain protein. Cell 110: 725-735, 2002.

64. Tanaka M, Chen Z, Bartunkova S, Yamasaki N and Izumo S: The cardiac homeobox gene Csx/ Nkx2.5 lies genetically upstream of multiple genes essential for heart development. Development 126: 1269-1280, 1999.

65. Biben C, Weber R, Kesteven S, Stanley E, McDonald L, Elliott DA, Barnett L, Köentgen F, Robb L, Feneley M and Harvey RP: Cardiac septal and valvular dysmorphogenesis in mice heterozygous for mutations in the homeobox gene $\mathrm{Nkx} 2-5$. Circ Res 87: 888-895, 2000.

66. Biben C and Harvey RP: Homeodomain factor Nkx2-5 controls left/right asymmetric expression of bHLH gene eHand during murine heart development. Genes Dev 11: 1357-1369, 1997.

67. Zou Y, Evans S, Chen J, Kuo HC, Harvey RP and Chien KR: CARP, a cardiac ankyrin repeat protein, is downstream in the Nkx2-5 homeobox gene pathway. Development 124: 793-804, 1997.

68. Thompson JT, Rackley MS and O'Brien TX: Upregulation of the cardiac homeobox gene Nkx2-5 (CSX) in feline right ventricular pressure overload. Am J Physiol 274: H1569-H1573, 1998.

69. Saadane N, Alpert L and Chalifour LE: Expression of immediate early genes, GATA- 4 , and Nkx-2.5 in adrenergic-induced cardiac hypertrophy and during regression in adult mice. Br J Pharmacol 127: 1165-1176, 1999.

70. Toko H, Zhu W, Takimoto E, Shiojima I, Hiroi Y, Zou Y, Oka T, Akazawa H, Mizukami M, Sakamoto M, Terasaki F, Kitaura Y, Takano H, Nagai T, Nagai R and Komuro I: Csx/Nkx2-5 is required for homeostasis and survival of cardiac myocytes in the adult heart. J Biol Chem 277: 24735-24743, 2002.

71. Kasahara H, Wakimoto H, Liu M, Maguire CT, Converso KL, Shioi T, Huang WY, Manning WJ, Paul D, Lawitts J, Berul CI and Izumo S: Progressive atrioventricular conduction defects and heart failure in mice expressing a mutant $\mathrm{Csx} / \mathrm{Nkx} 2.5$ homeoprotein. J Clin Invest 108: 189-201, 2001.

72. Hiroi Y, Kudoh S, Monzen K, Ikeda Y, Yazaki Y, Nagai R and Komuro I: Tbx5 associates with Nkx2-5 and synergistically promotes cardiomyocyte differentiation. Nat Genet 28: 276-280, 2001.

73. Sepulveda JL, Belaguli N, Nigam V, Chen CY, Nemer M and Schwartz RJ: GATA-4 and Nkx-2.5 coactivate Nkx-2 DNA binding targets: role for regulating early cardiac gene expression. Mol Cell Biol 18: 3405-3415, 1998.

74. Durocher D, Charron F, Warren R, Schwartz RJ and Nemer M: The cardiac transcription factors $\mathrm{Nkx} 2-5$ and GATA-4 are mutual cofactors. EMBO J 16: 5687-5696, 1997.

75. Chen CY and Schwartz RJ: Recruitment of the tinman homolog Nkx-2.5 by serum response factor activates cardiac alpha-actin gene transcription. Mol Cell Biol 16: 6372-6384, 1996.

76. Song K, Backs J, McAnally J, Qi X, Gerard RD, Richardson JA, Hill JA, Bassel-Duby R and Olson EN: The transcriptional coactivator CAMTA2 stimulates cardiac growth by opposing class II histone deacetylases. Cell 125: 453-466, 2006.

77. Kasahara H, Ueyama T, Wakimoto H, Liu MK, Maguire CT, Converso KL, Kang PM, Manning WJ, Lawitts J, Paul DL, Berul CI and Izumo S: Nkx2. 5 homeoprotein regulates expression of gap junction protein connexin 43 and sarcomere organization in postnatal cardiomyocytes. J Mol Cell Cardiol 35: 243-256, 2003.

78. Gutierrez-Roelens I, Sluysmans T, Gewillig M, Devriendt K and Vikkula M: Progressive AV-block and anomalous venous return among cardiac anomalies associated with two novel missense mutations in the $C S X / N K X 2-5$ gene. Hum Mutat 20: 75-76, 2002

79. Elliott DA, Kirk EP, Yeoh T, Chandar S, McKenzie F, Taylor P, Grossfeld P, Fatkin D, Jones O, Hayes P, Feneley M and Harvey RP: Cardiac homeobox gene NKX2-5 mutations and congenital heart disease: associations with atrial septal defect and hypoplastic left heart syndrome. J Am Coll Cardiol 41: 2072-2076, 2003

80. McElhinney DB, Geiger E, Blinder J, Benson DW and Goldmuntz E: NKX2.5 mutations in patients with congenital heart disease. J Am Coll Cardiol 42: 1650-1655, 2003. 
81. Reamon-Buettner SM and Borlak J: NKX2-5: an update on this hypermutable homeodomain protein and its role in human congenital heart disease (CHD). Hum Mutat 31: 1185-1194, 2010.

82. Wang J, Xin YF, Liu XY, Liu ZM, Wang XZ and Yang YQ: A novel NKX2-5 mutation in familial ventricular septal defect. Int J Mol Med 27: 369-375, 2011.

83. Qin X, Xing Q, Ma L, Meng H, Liu Y, Pang S and Yan B: Genetic analysis of an enhancer of the NKX2-5 gene in ventricular septal defects. Gene 508: 106-109, 2012.

84. Huang W, Meng H, Qiao Y, Pang S, Chen D and Yan B: Two novel and functional DNA sequence variants within an upstream enhancer of the human NKX2-5 gene in ventricular septal defects. Gene 524: 152-155, 2013.

85. Yan H, Yuan W, Velculescu VE, Vogelstein B and Kinzler KW: Allelic variation in human gene expression. Science 297: 1143, 2002.

86. Weisfeld-Adams JD, Edelmann L, Gadi IK and Mehta L: Phenotypic heterogeneity in a family with a small atypical microduplication of chromosome 22q11.2 involving TBX1. Eur J Med Genet 55: 732-736, 2012.
87. Smith H, Galmes R, Gogolina E, Straatman-Iwanowska A, Reay K, Banushi B, Bruce CK, Cullinane AR, Romero R, Chang R, Ackermann O, Baumann C, Cangul H, Cakmak Celik F, Aygun C, Coward R, Dionisi-Vici C, Sibbles B, Inward C, Kim CA, Klumperman J, Knisely AS, Watson SP and Gissen P: Associations among genotype, clinical phenotype, and intracellular localization of trafficking proteins in ARC syndrome. Hum Mutat 33: 1656-1664, 2012.

88. Soemedi R, Wilson IJ, Bentham J, Darlay R, Töpf A, Zelenika D, Cosgrove C, Setchfield K, Thornborough C, Granados-Riveron J, Blue GM, Breckpot J, Hellens S, Zwolinkski S, Glen E, Mamasoula C, Rahman TJ, Hall D, Rauch A, Devriendt K, Gewillig M, O' Sullivan J, Winlaw DS, Bu'Lock F, Brook JD, Bhattacharya S, Lathrop M, Santibanez-Koref M, Cordell HJ, Goodship JA and Keavney BD: Contribution of global rare copynumber variants to the risk of sporadic congenital heart disease. Am J Hum Genet 91: 489-501, 2012. 